\title{
Another Great Story
}

\author{
Wendy Doniger
}

\author{
The Roots of Hinduism: The Early Aryans and the Indus \\ Civilization \\ by Asko Parpola \\ Oxford University Press, 384 pp., USD\$35.00.
}

\section{A} SKO PARPOLA IS A prolific and learned historian of ancient India. In The Roots of Hinduism, he deploys his knowledge of archaeology, history, linguistics, and many languages to defend a number of highly original theories. The boldest of these concerns the relationship between the two great ancient cultures that thrived sequentially in the northwest of the South Asian subcontinent: the Indus Valley Civilization (IVC) and the Vedic people, composers of the Rig Veda, the most ancient and sacred Hindu text. The IVC flourished between 2,600 and 1,900 BCE. It was an urban world, rich in massive architectural structures and artistic remains, but one that left no decipherable texts. Roughly four centuries after the decline of the IVC, the nomadic culture of the Vedic people produced and preserved over a thousand glorious hymns, but their material traces amounted to no more than some shards of pottery.

Were the Sanskrit-speaking people who composed the Rig Veda rooted in the Indian soil, or had they entered India from Europe or Central Asia? If from Europe, these people would have spoken what used to be called Aryan or Indo-Aryan languages. These languages are now called Indo-European or Indo-Germanic or Indo-Iranian, for reasons of obvious historical delicacy. The Indo-European speakers may have migrated to India from the southern Russian steppes. ${ }^{1}$

Evidence for Indo-European migration into India is strong. It is based on datable proof of the use of horsedrawn vehicles throughout the area and linguistic material from Celtic and German, through Greek and Latin, to Hittite and Sanskrit. Its proponents have recently made claims of support from DNA evidence. ${ }^{2}$ Quoted in The Hindu, Martin Richards concluded that this was "very powerful evidence for a substantial Bronze Age migration from central Asia that most likely brought Indo-European speakers to India."
But the DNA evidence turned out to be either flimsy or irrelevant or both.

The opposing argument, that speakers of Indo-European languages were indigenous to the Indian subcontinent, is not supported by any reliable scholarship. It is now championed primarily by Hindu nationalists, whose religious sentiments have led them to regard the theory of Aryan migration with some asperity. Yet there probably was some sort of migration into India. If it was originally termed an Aryan invasion, this was only because the evidence was misinterpreted as suggesting widespread massacres, when, in fact, it was most likely disease, and not violence, that brought the IVC to its end. ${ }^{4}$ Needless to say, over the course of three hundred years of colonial rule, the British never much scrupled at either a migration or an invasion of India by white men.

They championed the Aryan invasion theory, and they were, essentially, correct.

Those who still argue in favor of indigenous Aryans also tend to identify the Vedic people with the people of the IVC, in the teeth of both textual evidence and archeology. One such piece of evidence is the fact that the Rig Veda is pervasively horsey, while the IVC is free of equine remains or images.

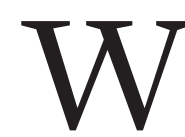

HILE THE ARTIFACTS of the IVC are immensely appealing, they do not answer the question whether there are non-Vedic or pre-Vedic sources for most of later Hindu culture. Parpola assumes that the Rig Veda was composed by people who had migrated from the Pontic-Caspian steppe. Major aspects of later Hinduism, he argues, are derived not from the Vedas, but from Harappan culture. Harappa was the first great IVC city to be excavated, lending its name to the whole of the Indus Valley Civilization. Threading the needle, Parpola insists that the Rig Veda was a product of the Indo-European migration, even as he argues that the Harappans contributed equally to Hindu culture.

Linguistic and archeological evidence, Parpola argues, indicates that late-Harappan culture was itself influenced by the Indo-Europeans who had migrated to the Indus Valley before the authors of the Rig Veda appeared on the 
scene. He believes that two waves of Indo-Aryans came to the area, the first around 2,900-2,000 BCE, and the second around 1,700-1,600 BCE. By this time they had begun to drift apart. ${ }^{5}$ The late Harappans interacted with the first wave; ${ }^{6}$ the second wave brought the Rig Veda. This argues for a Hinduism derived only in part from people who came from somewhere else, but minimizes the ethnic or linguistic divide between the two ancient cultures. To the extent that Harappan culture was significantly influenced by the Aryan migration, Parpola's own evidence undermines the power of his original argument that the Harappans contributed as much as the Aryans to Hindu culture.

Parpola's book is profusely illustrated and includes numerous images of tiny pictorial seals and other artifacts from the IVC, along with images from the wider Indo-European world, particularly Mesopotamia, with which the IVC had strong contacts. Parpola is intriguingly suggestive until he gets down to speculating about IVC religion, or to tracing specific connections between certain words and certain things.

Parpola divides the book into two sections, "The Early Aryans" and "The Indus Civilization," followed by a conclusion, in which he summarizes his arguments about the prehistory of Indo-Aryan languages and the relationship between Harappan religion and West and South Asia. "The trail of the Indo-Iranian languages," Parpola remarks, "from their East European homeland to their historical speaking areas can be followed in the archaeological record." This claim is supported by data that includes, but is not limited to, the distribution of Painted Gray Ware and its successor, Painted Black Ware. For example, he demonstrates that the Indo-Europeans ate horses before they harnessed them, and harnessed them before they rode them. But then Parpola engages in a long, complex, imaginative, and not entirely persuasive argument that the Iranian invasion into India-and here it is presented as an invasion, not a migration-is documented in the two great Sanskrit epics, the Mahabharata (usually dated between $300 \mathrm{BCE}$ and $300 \mathrm{CE}$ ), and the Ramayana (ca. 200 BCE-200 CE).

$\mathrm{P}$ ARPOla BEgins With the name of Pandu, father of the five Pandavas who are the heroes of the Mahabharata. "Pandu" in Sanskrit means pale. Pandu is cursed with paleness because his mother, disgusted by the dirty, smelly man who impregnated her, turned pale in revulsion. Having interrupted a couple in the sexual act, Pandu is cursed for the second time by being unable to beget children. His sons are born when his wife invokes gods as surrogate fathers.

I have always believed that paleness in this context is a surrogate for sterility. Not so Parpola. He argues that Pandu is pale because he is descended from pale Iranian horsemen, ${ }^{8}$ who entered India as part of the second wave of the *Proto-Indo-European (PIE) invasion. ${ }^{9}$ They con- quered the Kauravas, who had entered northern India in the first wave. To support this temporal framework, Parpola endorses the idea that the Mahabharata was originally written by the Kauravas. ${ }^{10}$ This theory is intended to explain the troubling fact that the self-proclaimed heroes of the poem, the Pandavas and their wily advisor Krishna, actually violate the cosmic laws of order (dharma) far more often than the putative villains, the Kauravas. Most scholars nowadays view this moral ambivalence in the Pandavas as the very point of the poem, which is the subtlety of dharma.

Parpola then turns to the other great Sanskrit epic, the Ramayana, which recounts King Rama's battle with Ravana, King of Lanka. Parpola argues that this, too, is the story of a Pandava conquest, this time of Lanka and South India. This argument ignores the fact that Lanka in the Ramayana is a mythical place. The island that was named Sri Lanka in 1972 was known before that as Simhadvipa and then Ceylon.

Parpola identifies Rama with Bala-Rama, the brother of Krishna in much later Sanskrit literature. Rama is married to Sita, whose name means "furrow" and who is herself born from a furrow. Bala-Rama's emblem is the plough. As the plough is the husband of the furrow, Bala-Rama is thus the husband of Sita. This is an exquisitely speculative identification.

Parpola sees Rama and Krishna as the Kauravas, the guardians of the older Vedic tradition in Harappa. These Harappan brothers were ostensibly the descendants of twin equine Vedic gods, the Ashvins, ${ }^{11}$ who entered Harappan culture with the first PIE wave. ${ }^{12}$ Both Rama and Krishna were said to be dark; "Krishna" means dark in Sanskrit. The Pandava Arjuna's name, by way of contrast, means silver. ${ }^{13}$ As further evidence that the Pandavas were Iranian, Parpola cites the fact that all five Pandavas were married to the same woman, Draupadi, in violation of Hindu law, and he quotes Herodotus on the polyandrous habits of the Iranians..$^{14}$ He thus concludes that the Kaurava kingdom corresponds closely to the early phase (c. 1,100-700 BCE) of Vedic culture. "The legendary war between the Kauravas and the Pandavas, the main story of the Mahabharata," remarks Parpola, "seems to have taken place during the latter phase [of Vedic culture] (c. 700-350 BCE)." ${ }^{15}$

It is striking that even in the midst of this complex historical reconstruction, Parpola does note, in passing, that the Mahabharata's war is legendary. Indeed it is. Like the Lanka of the Ramayana, it is not about the invasion of India by Indo-Europeans, Pandavas, or anyone else. The Mahabharata battle is a war between cousins, members of the same family, and not an invasion by linguistic or racial foreigners. The Ramayana tells the tale of a princess stolen by a demon and rescued by her heroic prince. It is a familiar story in many, many cultures. There is no evidence to support Parpola's historical interpretation. 
$\mathrm{P}$ ARPOLA PRESENTS A DETAILED and richly illustrated survey of the archaeology of the IVC, using this information to strengthen his arguments about the origins of Hindu culture. This is the most interesting and controversial part of the book. I have supported the thesis that there is some form of continuity between the IVC and later Hinduism. ${ }^{16} \mathrm{I}$ am now more than ever persuaded that IVC culture survived the destruction of its cities, and that later Hindu imagery, having entered Hinduism after the Vedic period, may well be derived from the IVC. But I remain skeptical about Parpola's reconstruction of the IVC's religion. In particular, I disagree with his arguments about the language of the IVC, and I am not persuaded by his claim to have deciphered some of the written symbols.

Parpola cites John Marshall's 1931 report on the excavations at Mohenjo-Daro. Marshall noted that crocodiles, buffaloes, fig-trees, peacocks, and fish are "important motifs of Early and Mature Harappan painted pottery, which are also among the principal religious symbols of "village Hinduism."'17 Parpola also notes that Vedic gods were not worshipped as images; they were heard, not seen. Hindu gods, by contrast, were worshipped as images, a practice that may well have been inherited from the IVC. ${ }^{18}$ But here we encounter a widespread, but unjustified, assumption, that all statues-indeed, all of the IVC images-are religious in nature. Parpola's claim that "folk religion in all cultures is notably conservative" is also a misguided generalization. ${ }^{19}$ These two assumptions lead Parpola to conclude that images in the IVC had the same meaning-a religious meaning-as similar images that appear in later Hinduism.

Consider the large bathing tank found in the citadel at Mohenjo-Daro, which is forty by twenty-three feet in length and width, and eight feet deep. To Parpola, this suggests ritual bathing, central to later Hinduism. ${ }^{20}$ But all that this structure really tells us is that the people of the IVC liked to bathe. Another example: noting the many images of women in the IVC, Parpola argues that the worship of Durga in "village Hinduism" is connected to the worship of Mesopotamian and Harappan fertility goddesses. The Rig Vedic goddess of speech, Vac, Parpola argues, also has Mesopotamian or Harappan origins. ${ }^{21} \mathrm{But}$ not every woman is a goddess, and why should images of women symbolize fertility-or, indeed, speech?

IVC sculptors favored male animals, especially those with horns: bulls, water buffaloes, rams, and even a tiger with horns. ${ }^{22}$ On seals, pottery, and figurines, male animals are the favorite subject, most frequently bulls with pendulous dewlaps and big pizzles. IVC sculptors did not find female animals very interesting. No cows appear. ${ }^{23}$ The art-historical record thus tells us that the artists of the IVC did not use cows as cultural symbols. Why, then, should we assume-with Marshall and, after him, Parpola-that cows were sacred in the IVC?
Similar problems arise in the interpretation of buffaloes. Parpola assumes that buffalo sculptures show that people of the IVC worshipped the buffalo; ${ }^{24}$ the Harappan buffalo sacrifice, he argues, was replaced by the Vedic horse sacrifice. ${ }^{25}$ But why assume that buffaloes were sacrificed, rather than merely eaten, or harnessed for use? The IVC images of animals and plants are often breathtakingly beautiful, and highly imaginative. Might they not simply be artistic images springing from the human impulse to create art, an impulse every bit as universal as the impulse to worship? Why must the wonderful fig trees at Harappa be the source of sacred trees in Hinduism? ${ }^{26}$

Some imagery, it is true, suggests something more than everyday life: a carved seal, for example, on which a seated or kneeling figure is flanked by two other figures and an erect cobra. ${ }^{27}$ Parpola interprets the seated figure as a god and the other figures as worshippers. They may just be bystanders, but how to explain the cobra? Still another human figure holds back two rearing tigers; a creature half bull and half man attacks a horned tiger. This is not a snapshot of daily life in the IVC. Scenes and figures such as these may give us a glimpse of ritual, but nothing approaching persuasive evidence.

$\mathrm{P}$ ARPOla assumes throughout his book that the language of the IVC was an ancient form of Dravidian. Entirely distinct from the Indo-European language family, Dravidian comprises Tamil, as well as Telugu, Malayalam, and several other languages. Dravidian languages are spoken mainly in southern India, and parts of eastern and central India, particularly Gujarat and Maharashtra, as well as in Sri Lanka, with small pockets in southwestern Pakistan.

"The Harappan language," Parpola asserts, "could not possibly have disappeared without leaving traces in the Vedic texts." ${ }^{28}$ Well and good. But Parpola then argues that Harappan cannot be Indo-European, ${ }^{29}$ and that most likely it was Dravidian, the language family spreading south from the Indus Valley and down the west coast of India, where it left traces in Gujarat and Maharashtra. ${ }^{30}$ Brahui, a Dravidian language, is still spoken in the Indus Valley. Parpola's belief that the Harappan language was Dravidian "is supported by the many Dravidian loanwords in the Vedic language, including the oldest available source, the Rigveda." ${ }^{31}$ He lists a number of well-documented loanwords in Vedic Sanskrit and argues that these words stem from Dravidian-speaking Harappan culture. ${ }^{32}$ Parpola's linguistic argument is weakened by the fact that many of his examples are taken from reconstructed *Proto-Dravidian, which is more speculative even than *Proto-Indo-European.

Sometimes Parpola uses Mesopotamian and Sumerian parallels to guess at the meaning of Indus signs. He assumes that "[t]he Harappans' long-time presence in West Asia makes it highly probable that the same content 
may be expected in the Indus seal inscriptions, whether they are found in Mesopotamia or the Indus Valley."33 Interpreted signs, Parpola argues, form mutually supportive compound words, their denotata suggesting Harappan objects. These signs match compound words in Dravidian languages. ${ }^{34}$

Consider a recurring series of signs each suggesting a fish. Since the sign does not occur on Mesopotamian seals, "it is likely," Parpola suggests, "that in the Indus seal inscriptions the fish sign denotes something other than fish and may be used as a rebus." ${ }^{35}$ Perhaps it signifies a star? There are no IVC signs that look like stars. But on the assumption that fish signs better designate stars than star signs, Parpola concludes that the sign denotes a star. ${ }^{36}$

This becomes the basis for his astronomical and astrological interpretations of several seals. A figure like a trident resembles a figure painted on Harappan pottery. It is a three-branched fig tree, Parpola suggests. ${ }^{37}$ The Sanskrit word for fig tree, vatam, comes from a *Proto-Dravidian word for banyan, and that word is a homonym for the *Proto-Dravidian word for north. The fish sign and the fig tree sign together designate the North $\mathrm{Star}^{38} \mathrm{~A}$ seal with seven lines plus the fish sign designates Ursa Major. ${ }^{39}$ A seal with six lines plus the fish sign may refer to the Pleiades..$^{40}$ A sign on still another seal suggests a roof. The Tamil for roof is a homophone for black. Parpola's algebra is thus roof [black] + fish [star] = black star. In old Tamil, Saturn is called the black star. ${ }^{41}$ This sign thus represents Saturn.

In many instances, Parpola's desire and imagination run far ahead of the evidence. But he is always imaginative and there is something wonderful to learn on every page. Parpola seems almost undone by his own extraordinary knowledge. Any word suggests fifteen others, and any image, fifty others. Under the impression that the more things are linked, the better the case they make, Parpola succeeds only in making his argument less structured and less persuasive.

In the end, his story is yet another great story of India, another myth like the Mahabharata and the Ramayana.

Wendy Doniger is the Mircea Eliade Distinguished Service Professor of the History of Religions at the University of Chicago.

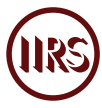

1. The literature on the Aryan migration debate is vast, but it is well summarized by Edwin Bryant and Laurie Patton, The Indo-Aryan Controversy: Evidence and Inference in Indian History (London: Routledge, 2005).

2. An article published in BMC Evolutionary Biology in March 2017 argued:
[G]enetic influx from Central Asia in the Bronze Age [3000 BCE to $1500 \mathrm{BCE}$ ] was strongly male-driven, consistent with the patriarchal, patrilocal, and patrilineal social structure attributed to the inferred pastoralist early Indo-European society. This was part of a much wider process of Indo-European expansion, with an ultimate source in the Pontic-Caspian region, which carried closely related Y-chromosome lineages ... across a vast swathe of Eurasia between 5,000 and 3,500 [years ago].

Marina Silva et al., "A Genetic Chronology for the Indian Subcontinent Points to Heavily Sex-Biased Dispersals," in BMC Evolutionary Biology (2017).

3. Tony Joseph, "How Genetics is Settling the Aryan Migration Debate," The Hindu, June 16, 2017.

4. Romila Thapar, Early India: From the Origins to 1300 (London: Penguin, 2002; Berkeley: University of California Press, 2004), 87.

5. Asko Parpola, The Roots of Hinduism: The Early Aryans and the Indus Civilization (Oxford: Oxford University Press, 2015), 298, 300.

6. Parpola, Roots of Hinduism, 197. He argues that the first wave brought the Atharva Veda, a text generally dated several centuries after the Rig Veda but one that, according to him, contains language actually older than that of the Rig Veda. See Parpola, Roots of Hinduism, 131.

7. Parpola, Roots of Hinduism, 314.

8. Parpola, Roots of Hinduism, 145.

9. Parpola, Roots of Hinduism, 145-6. * Denotes a hypothetical reconstructed form of the language.

10. Parpola, Roots of Hinduism, 148, citing Moriz Winternitz, $A$ History of Indian Literature, trans. Silavati Ketkar (Calcutta: University of Calcutta, 1927), I 454-56. This viewpoint is also reflected in the work of several other nineteenth-century scholars.

11. Known in Greece and Rome as the Dioscuroi and the Gemini.

12. Parpola, Roots of Hinduism, 301.

13. Parpola, Roots of Hinduism, 155-57.

14. Parpola, Roots of Hinduism, 149; Herodotus, History, 1.216.

15. Parpola, Roots of Hinduism, 299.

16. Parpola cites "a skeptical Wendy Doniger in one of the best current assessments of the Indus religion.” Parpola, Roots of Hinduism, 25-26. Parpola cites Wendy Doniger, The Hindus: An Alternative History (Penguin Books, New York, 2009), 82-83.

17. Parpola, Roots of Hinduism, 306. See also John Marshall, Mohenjo-Daro and the Indus Civilization. Being an Official Account of Archaeological Excavations at Mohenjo-Daro Carried Out by the Government of India between the Years 1922 and 1927, with Plan and Map in Colours, and 164 Plates in Collotype (London: Arthur Probsthain, 1931).

18. Parpola, Roots of Hinduism, 173.

19. Parpola, Roots of Hinduism, 175.

20. Parpola, Roots of Hinduism, 25, 174. 
21. Parpola, Roots of Hinduism, 241.

22. Thomas Hopkins, Roots of Hinduism (Encino, CA: Dickenson, 1971), 5-8.

23. Parpola, Roots of Hinduism, 241.

24. Parpola, Roots of Hinduism, 175.

25. Parpola, Roots of Hinduism, 174.

26. Parpola, Roots of Hinduism, 180.

27. Parpola, Roots of Hinduism, 286.

28. Parpola, Roots of Hinduism, 305.

29. Parpola, Roots of Hinduism, 164.

30. Parpola, Roots of Hinduism, 166.
31. Parpola, Roots of Hinduism, 305.

32. Parpola, Roots of Hinduism, 168-69.

33. Parpola, Roots of Hinduism, 270.

34. Parpola, Roots of Hinduism, 305.

35. Parpola, Roots of Hinduism, 271.

36. Parpola, Roots of Hinduism, 271.

37. Parpola, Roots of Hinduism, 278.

38. Parpola, Roots of Hinduism, 203.

39. Parpola, Roots of Hinduism, 274-5.

40. Parpola, Roots of Hinduism, 274.

41. Parpola, Roots of Hinduism, 276. 